\title{
Developing a global core competency framework for clinical research
}

\author{
Tamzin Furtado ${ }^{1,2}$, Amélie Julé ${ }^{12^{*}}$, Liam Boggs ${ }^{1,2}$, Francois van Loggerenberg ${ }^{1,2}$, Victoria Ewing ${ }^{1,2}$, Trudie Lang ${ }^{1,2}$ \\ From 3rd International Clinical Trials Methodology Conference \\ Glasgow, UK. 16-17 November 2015
}

Lack of recognition for working in clinical research is widely cited as an impediment to its conduct. There is a lack of career structure for the many roles involved (investigators, trial managers, nurses, etc.), and a lack of understanding of who does what. Competency frameworks exist for some individual job roles, but these are infrequent; thus the need for a global framework describing roles and responsibilities in a research team. This would facilitate appraisal of staff, promote career development by highlighting acquired skills, and illuminate areas where training opportunities are lacking.

In this project, we combine 28 frameworks created by external groups, with information from 116 job descriptions obtained from partners in clinical trial units worldwide and from the web, to create a widely-encompassing framework derived from 11 different roles. Using qualitative analysis software, we systematically assess the activities performed by the clinical research team to categorise them and define underlying competencies - knowledge-, skill- or task-based. The resulting framework counts 50 competencies required throughout the trial lifecycle, from assessment of scientific literature to results dissemination via project management, public engagement or grant application. It is applicable to studies that may differ in design, geographical location, disease, etc., and can be adapted to the particular needs of specific projects or roles.

This "Global Core Competency Framework for Clinical Research" is currently being validated through consultations with experts in collaboration with WHO-TDR, in order to refine its completeness and accuracy, as well as its practicability before it is deployed into the field.

\section{Authors' details \\ ${ }^{1}$ The Global Health Network, Oxford, UK. ${ }^{2}$ Centre for Tropical Medicine and} Global Health, University of Oxford, Oxford, UK.

The Global Health Network, Oxford, UK

Full list of author information is available at the end of the article
Published: 16 November 2015

doi:10.1186/1745-6215-16-S2-P191

Cite this article as: Furtado et al:: Developing a global core competency framework for clinical research. Trials 2015 16(Suppl 2):P191.
Submit your next manuscript to BioMed Central and take full advantage of:

- Convenient online submission

- Thorough peer review

- No space constraints or color figure charges

- Immediate publication on acceptance

- Inclusion in PubMed, CAS, Scopus and Google Scholar

- Research which is freely available for redistribution

Submit your manuscript at www.biomedcentral.com/submit

\section{() Biomed Central}

C Biomed Central

(c) 2015 Furtado et al. This is an Open Access article distributed under the terms of the Creative Commons Attribution License (http:// creativecommons.org/licenses/by/4.0), which permits unrestricted use, distribution, and reproduction in any medium, provided the original work is properly cited. The Creative Commons Public Domain Dedication waiver (http://creativecommons.org/publicdomain/ zero/1.0/) applies to the data made available in this article, unless otherwise stated. 